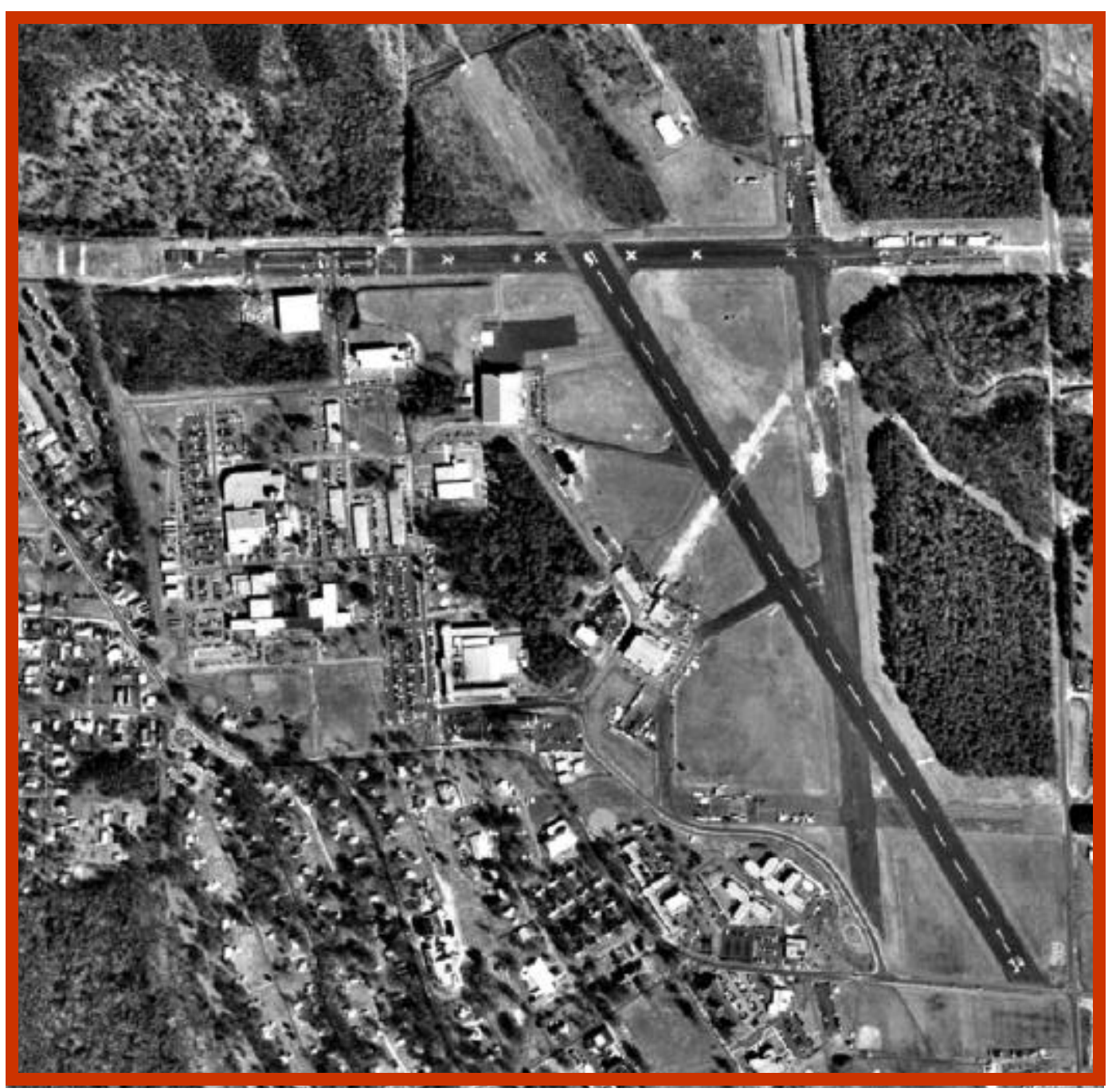

\title{
Final MTI Data Report: Dahlgren Naval Surface Warfare Center (U)
}

Westinghouse Savannah River Company

October 2002

Savannah River Site

Aiken, SC 29808

Prepared for the U. S. Department of Energy under contract no. DE-AC09-96SR18500 
This document was prepared in conjunction with work accomplished under Contract No. DE-AC09-96SR18500 with the U. S. Department of Energy.

\section{DISCLAIMER}

This report was prepared as an account of work sponsored by an agency of the United States Government. Neither the United States Government nor any agency thereof, nor any of their employees, makes any warranty, express or implied, or assumes any legal liability or responsibility for the accuracy, completeness, or usefulness of any information, apparatus, product or process disclosed, or represents that its use would not infringe privately owned rights. Reference herein to any specific commercial product, process or service by trade name, trademark, manufacturer, or otherwise does not necessarily constitute or imply its endorsement, recommendation, or favoring by the United States Government or any agency thereof. The views and opinions of authors expressed herein do not necessarily state or reflect those of the United States Government or any agency thereof.

This report has been reproduced directly from the best available copy.

Available for sale to the public, in paper, from: U.S. Department of Commerce, National Technical Information Service, 5285 Port Royal Road, Springfield, VA 22161, phone: (800) 553-6847, fax: (703) 605-6900

email: orders@ntis.fedworld.gov

online ordering: http://www.ntis.gov/help/index.asp

Available electronically at http://www.osti.gov/bridge

Available for a processing fee to U.S. Department of Energy and its contractors, in paper, from: U.S. Department of Energy, Office of Scientific and Technical Information, P.O. Box 62, Oak Ridge, TN 37831-0062,

phone: (865)576-8401,

fax: (865)576-5728

email: $\underline{\text { reports@ adonis.osti.gov }}$ 


\title{
Final MTI Data Report: Dahlgren Naval Surface Warfare Center (U)
}

\author{
Prepared by \\ M. J. Parker \\ Westinghouse Savannah River Company \\ Aiken, SC 29808 \\ M. M. Pendergast \\ SMP Enterprises \\ Augusta, GA 30907 \\ A. J. Garrett \\ Westinghouse Savannah River Company \\ Aiken, SC 29808
}

October 2002 
WSRC-TR-2002-00487

Final MTI Data Report: Dahlgren Naval Surface Warfare Center (U)

Savannah River Technology Center

This page intentionally left blank. 


\section{TABLE OF CONTENTS}

Introduction .................................................................................................... 1

Paved Surface Temperature Measurements ....................................................... 1

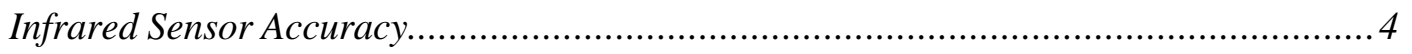

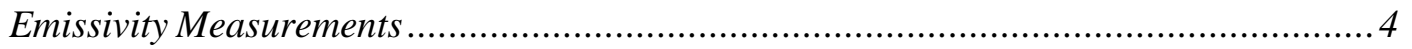

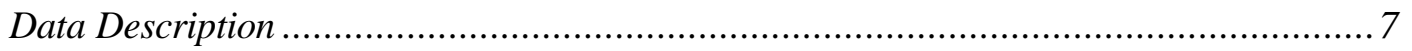

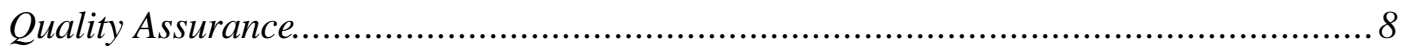

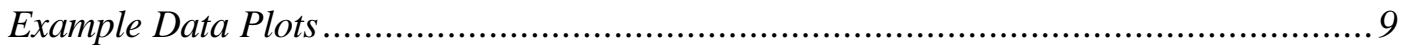

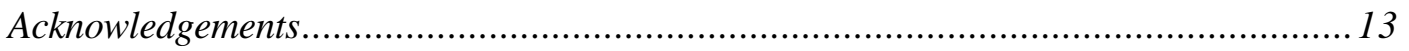

\section{LIST OF F IGURES}

Figure 1. Location of the Dahlgren Naval Surface Warfare Center............................. 1

Figure 2. The Portable Temperature Apparatus .................................................. 2

Figure 3. The Location of the Temperature Sensor Apparatus .................................. 3

Figure 4. Comparison of Blackbody Temperatures and Infrared Sensors of Differing

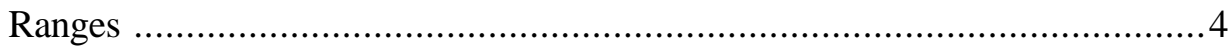

Figure 5. Close-Up of the Tarmac Where the Temperature Apparatus Was Installed.......7

Figure 6. Temperature Time Series in March 2001 ............................................... 10

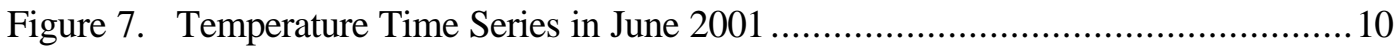

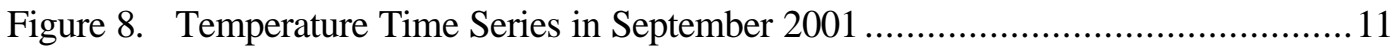

Figure 9. Temperature Time Series Before, During, and After Sensor Cleaning ...........11

Figure 10. Temperature Time Series in December 2001 ........................................... 12 


\section{LIST OF TABLES}

Table I. Paved Surface Temperature Measurement Apparatus Data .......................... 3

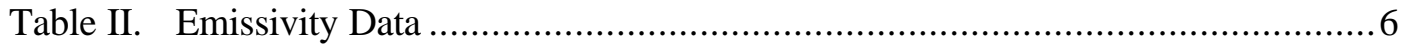

Table III Description of Dahlgren Temperature Measurements ............................... 7

Table IV Data Quality Assurance Matrix ................................................... 8 


\section{INTRODUCTION}

During the period from February 2001 to August 2002, paved-surface (tarmac) temperatures were collected at the Dahlgren Naval Surface Warfare Center (Figure 1). This effort was led by the Savannah River Technology Center (SRTC), with the assistance of base personnel, as part of Savannah River Technology Center's (SRTC) ground truth mission for the US Department of Energy's Multispectral Thermal Imager (MTI) satellite (Garrett, et al, 1999). Data described in this report are available from the authors (contact information provided at the end of report).

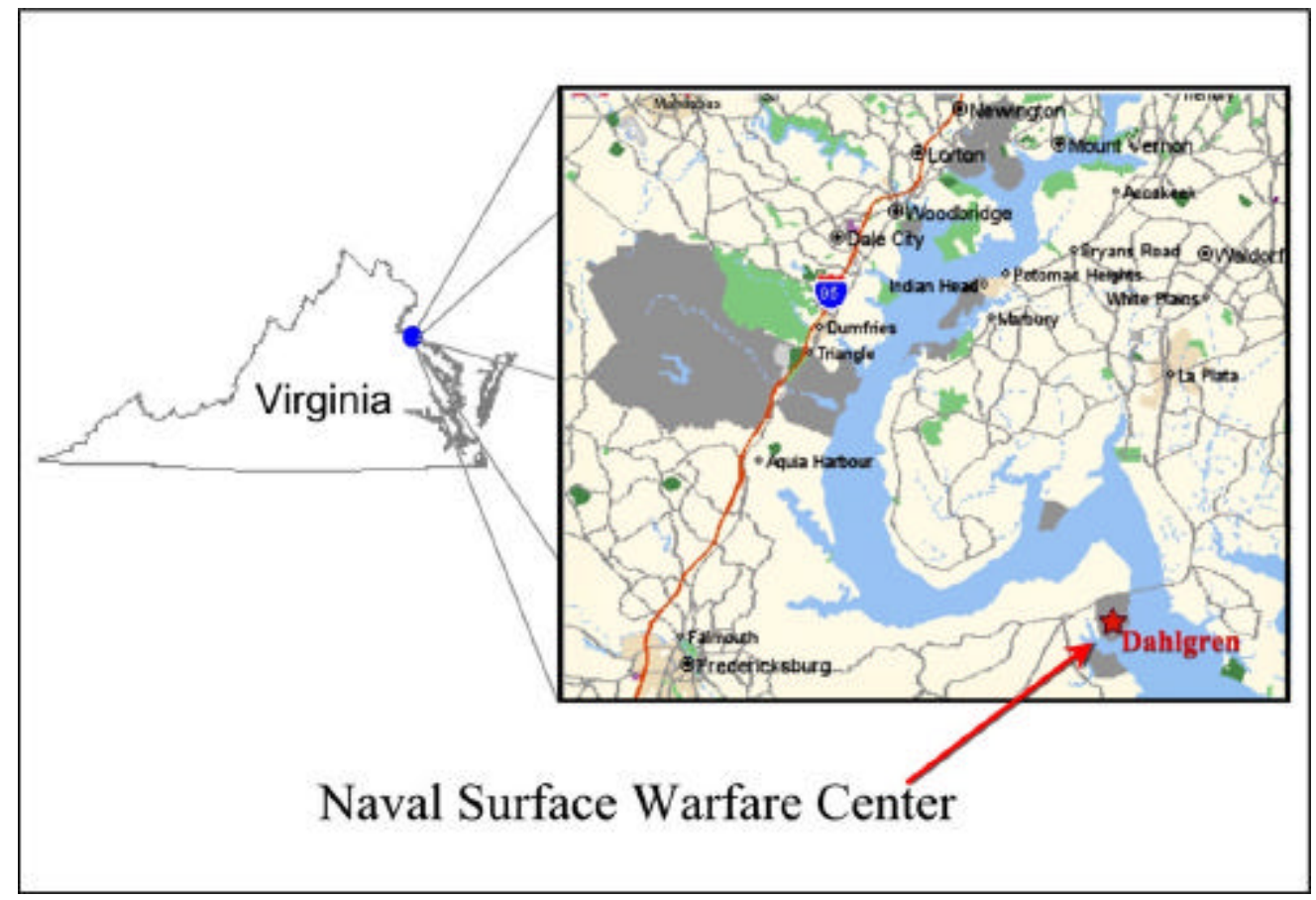

Figure 1. Location of the Dahlgren Naval Surface Warfare Center.

\section{Paved Surface Temperature Measurements}

SRTC's intent was to measure tarmac temperatures during MTI image times. Since image times were not known in advance, a continuous monitoring system was installed for long-term data collection. Surface temperatures can be measured either by direct means with an imbedded sensor or indirectly with a "remote," or non-contact sensor. For the Dahlgren site, both methods were used with the presumption that the non-contact sensor would be superior since a larger portion of the surface would be measured to obtain a representative reading. 
However, the imbedded sensor, a "point" measurement, would prove to be a worthwhile "sanity" check and source of data when the remote sensor(s) was not operating properly.

Paved surface temperature measurements were made with inexpensive infrared sensors manufactured by Omega ${ }^{\circledR}$ and a buried copper-constantin thermocouple. The infrared sensors mimic a Type $\mathrm{T}$ thermocouple and have a field of view of 2 to 1 . For example, a sensor $0.5 \mathrm{~m}$ above ground would sense over a $1 \mathrm{~m}$-diameter area directly below the sensor. Sensors were selected according to measurement ranges (Table I) that were expected to occur over the course of a given year.

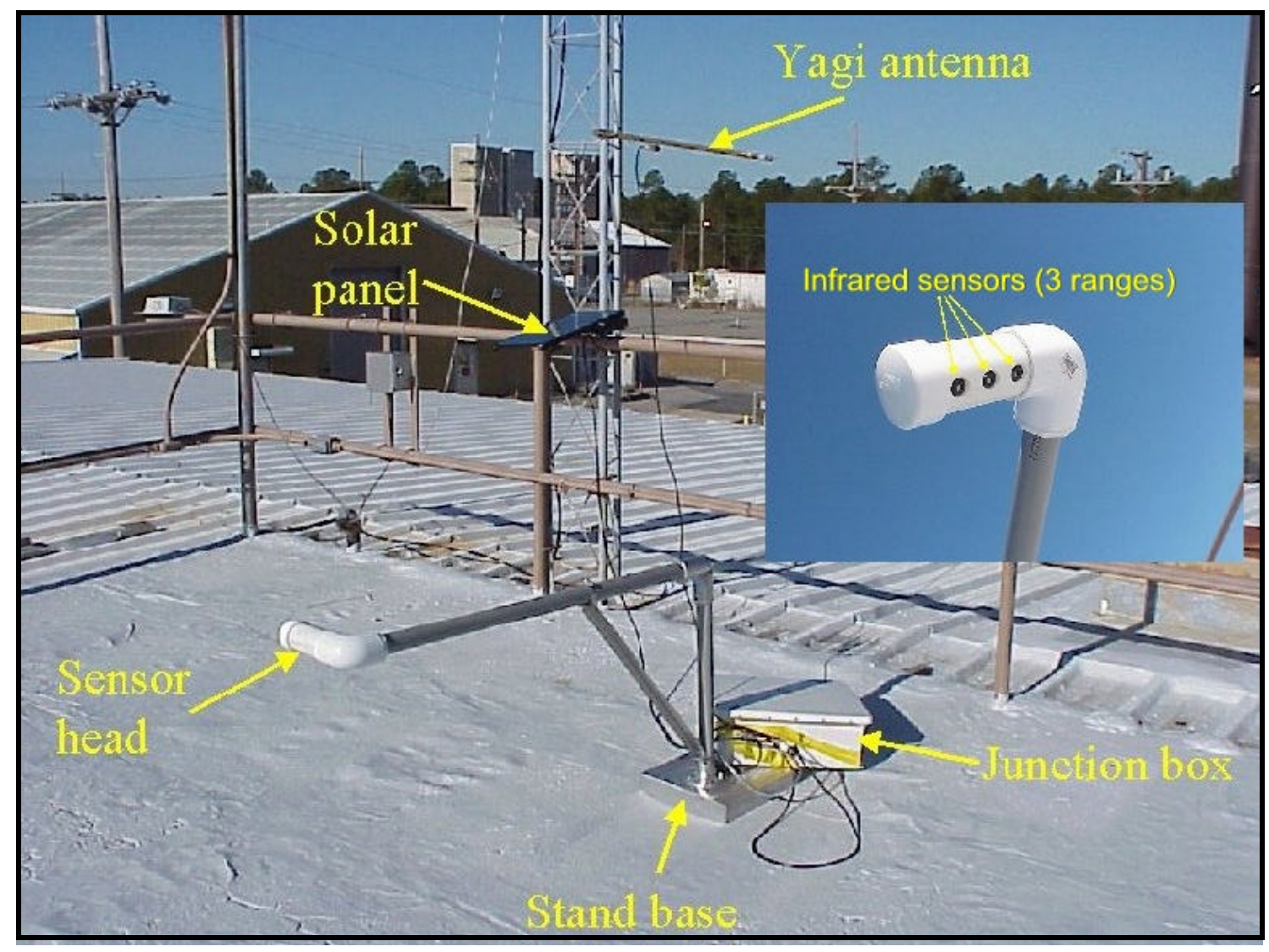

Figure 2. The portable temperature apparatus with its various components including the sensor head shown in the inset image. The Yagi antenna is used for cellular phone communications and remote data downloading. The junction box houses the datalogger, battery, and cellular phone.

An apparatus was built to house the sensors so that measurements were not influenced by solar reflections (Figure 2). Three infrared sensors were mounted inside the sensor head (Figure 2 [inset]). An additional thermistor (not shown) was installed inside the 


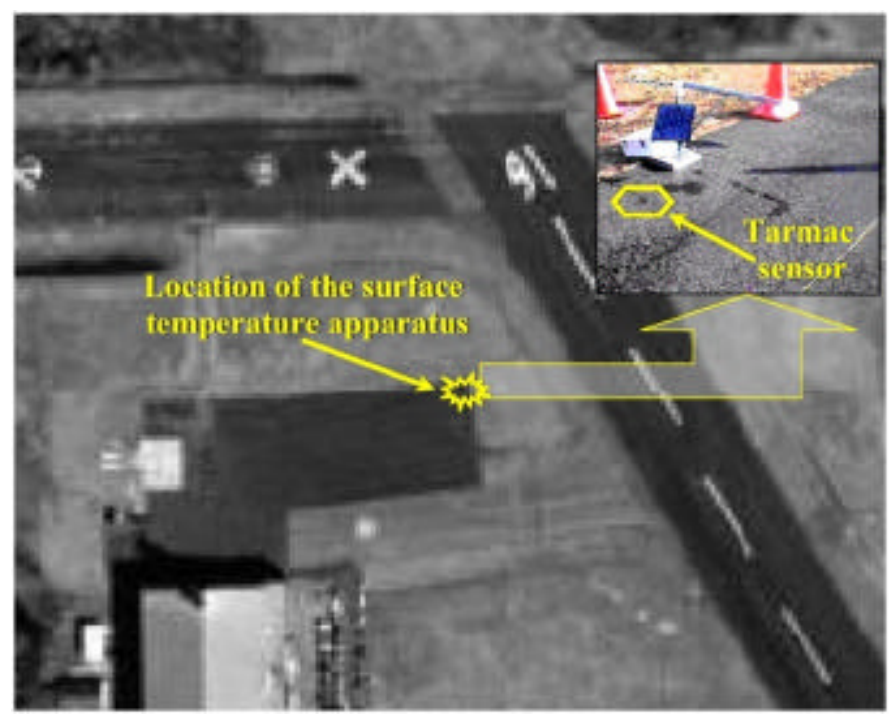

Figure 3. The location of the temperature sensor apparatus at the edge of the tarmac (inset). See cover image for an overview of the entire Dahlgren Naval Surface Warfare Center site.

sensor head and the copper-constantin thermocouple was buried in a small crevice in the tarmac (Figure 3). The apparatus was installed at the edge of an airstrip (Figure 3) and was grounded to avoid damaging lightning induced electrical surges. Data were logged with a Campbell Scientific ${ }^{\circledR}$ datalogger and were polled remotely via cellular phone. Power was supplied with a 12 volt DC battery and solar panel battery charger.

Table I

\section{Paved Surface Temperature Measurement Apparatus Data}

Location (based on WGS 84 datum) $\quad \mathrm{N} 38.336844^{\circ}, \mathrm{W} 77.041053^{\circ}$

Name

Low

Medium

High

Tarmac

Sensor head
Type (Manufacturer)

Infrared(Omega)

Infrared(Omega)

Infrared(Omega)

Copper-Constantine Thermocouple(Omega)

Thermistor (Campbell Scientific)
Range

$\left(-18^{\circ} \mathrm{C}\right)$ to $27^{\circ} \mathrm{C}$

$10^{\circ} \mathrm{C}$ to $49^{\circ} \mathrm{C}$

$25^{\circ} \mathrm{C}$ to $80^{\circ} \mathrm{C}$

$\left(-60^{\circ} \mathrm{C}\right)$ to $100^{\circ} \mathrm{C}$

$\left(-35^{\circ} \mathrm{C}\right)$ to $50^{\circ} \mathrm{C}$ 


\section{INFRARED SENSOR ACCURACY}

The low, medium, and high range infrared sensors were compared to a National Institute for Standards and Testing (NIST) traceable blackbody standard in laboratory conditions. Figure 4 shows the relative accuracy of each sensor (note that two of each type were tested) against the blackbody. Errors of approximately $0.1^{\circ} \mathrm{C}$ or less in the mid-range of the sensors were observed with higher errors near the endpoints of the sensing ranges.

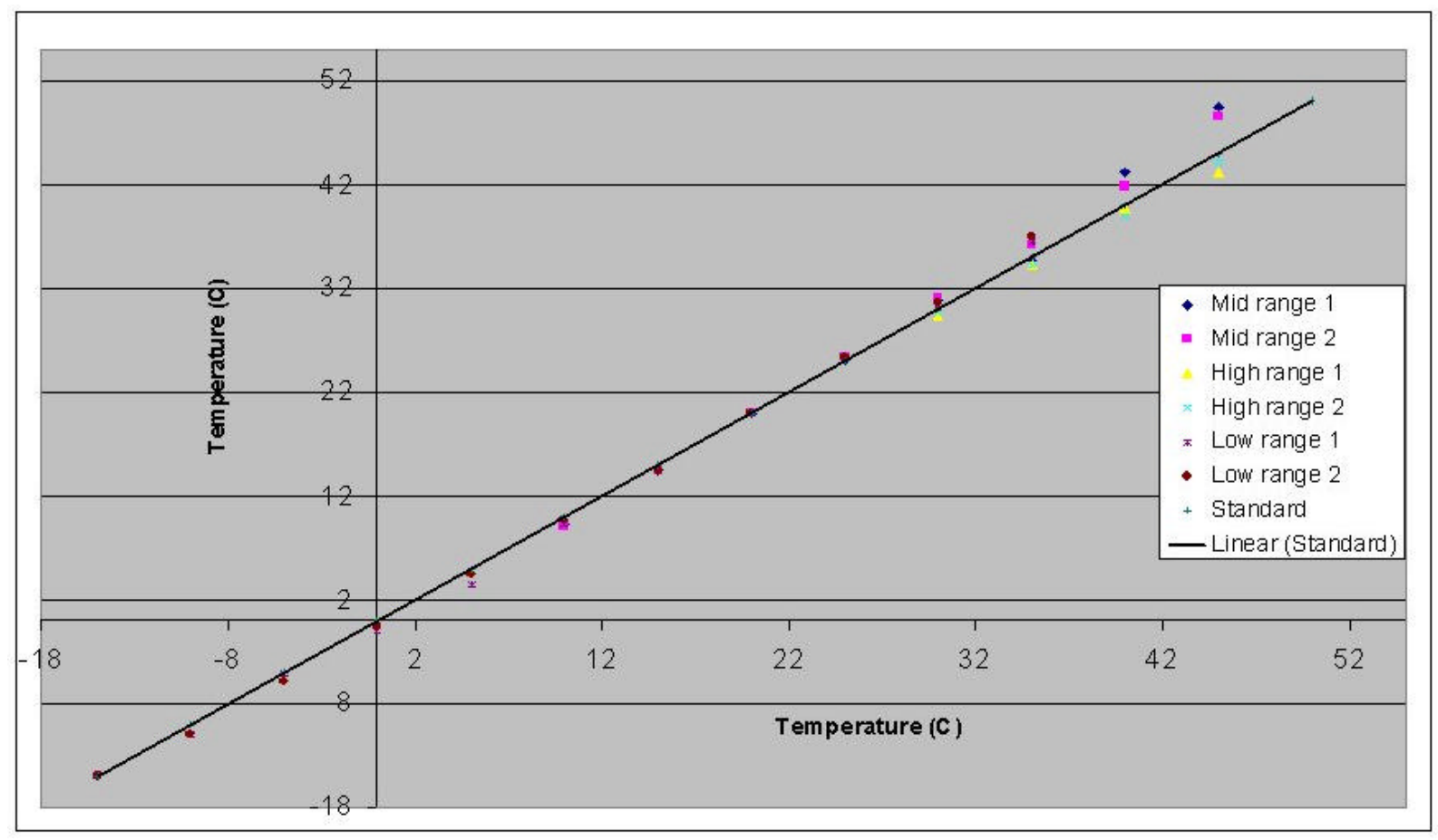

Figure 4. Comparison of blackbody (standard) temperatures and infrared sensors of differing ranges. The solid line ("Linear (Standard)") indicates the best fit for the blackbody data.

The actual accuracy during field deployment is lessened by two main factors including cleanliness and misalignment of the optics. As will be shown in sections entitled, "Quality Assurance" and "Example Data Plots", the degradation of measurements became quite obvious as the sensor lenses became dirty. After cleaning, measurements improved dramatically. Misalignment of the sensors can cause the field of view to be altered such that too much reflected light enters the sensor. This can cause erroneous measurements that are not totally representative of the actual target surface. Based on these factors, the actual measured tarmac temperatures are probably within $\pm 1^{\circ} \mathrm{C}$ of the actual temperature. Additionally, the imbedded copper-constantin thermocouple probably has a similar accuracy of $\pm 1^{\circ} \mathrm{C}$ based on errors associated with non-representativeness of the actual measurement location (i.e. not on the surface, but slightly under the surface). At night, the infrared (barring un- 
clean optics) and copper-constantin measurements should be more accurate due to a lack of detrimental effects of incoming solar radiation.

\section{EMISSIVITY MEASUREMENTS}

The temperature measurements made with the infrared sensors must be adjusted according to the emissivity (ratio of the total radiant energy per unit area emitted to an ideal or "blackbody" radiator) of the surface being measured. After the temperature apparatus was installed, a Heiman ${ }^{\circledR}$ KT-19 radiometer with an attached cone reflector was used to characterize the emissivity of the tarmac in the vicinity of the apparatus and nearby taxiway and runway. A hand-held GPS device was used to determine approximate position and pictures were obtained with a low-resolution digital camera. Table II shows the data gathered and collected by and during this analysis, and Figure 5 shows a close-up of the tarmac under the temperature sensor.

At selected way points, measurements were made of: 1) the ground surface temperature $\left(\mathrm{T}_{\mathrm{h}}\right)$ with the radiometer held at about a $1 \mathrm{~m}$ height, and 2) ground surface temperature $\left(\mathrm{T}_{\mathrm{c}}\right)$ with the cone on the ground surface, and 3) the sky temperature $\left(\mathrm{T}_{\text {sky }}\right)$ at about $45^{\circ}$ elevation away from the Sun. These data were used to calculate a value, which is an approximation to the surface emissivity from the following equation.

$$
\text { Emissivity }=\left(\mathrm{T}_{\mathrm{h}}{ }^{4}-\mathrm{T}_{\mathrm{sky}}{ }^{4}\right) /\left(\mathrm{T}_{\mathrm{c}}{ }^{4}-\mathrm{T}_{\mathrm{sky}}{ }^{4}\right)
$$

As an example, a measured temperature of $30^{\circ} \mathrm{C}$, with a sky temperature of $\left(-40^{\circ} \mathrm{C}\right)$ and a surface emissivity of 0.95 would yield an actual ground surface temperature of $29.1^{\circ} \mathrm{C}$. 
Table II

\begin{tabular}{|c|c|c|c|c|c|c|}
\hline \multicolumn{7}{|c|}{ Emissivity Data } \\
\hline Way Point & $\mathbf{E}$ & $\mathbf{N}$ & Date & Time (GM) & $\mathrm{AE}$ & Comments \\
\hline 1 & 321620 & 4245154 & 7-Feb-01 & $20: 25$ & & Location of Temp apparatus \\
\hline 2 & 321617 & 4245143 & 7-Feb-01 & $20: 34$ & 0.958 & \\
\hline 3 & 321620 & 4245143 & 7-Feb-01 & $20: 34$ & 0.953 & \\
\hline 4 & 321610 & 4245130 & 7-Feb-01 & 20:36 & 0.95 & \\
\hline 5 & 321589 & 4245121 & 7-Feb-01 & $20: 37$ & 0.946 & \\
\hline 6 & 321561 & 4245120 & 7-Feb-01 & $20: 39$ & 0.949 & \\
\hline 7 & 321543 & 4245112 & 7-Feb-01 & $20: 41$ & 0.959 & \\
\hline 8 & 321513 & 4245136 & 7-Feb-01 & $20: 45$ & 0.977 & dark,damp? \\
\hline 9 & 321543 & 4245144 & 7-Feb-01 & $20: 48$ & 0.954 & \\
\hline 10 & 321602 & 4245149 & 7-Feb-01 & $20: 50$ & 0.955 & \\
\hline 11 & 321618 & 4245155 & 7-Feb-01 & 20:53 & 0.955 & Near Temp apparatus \\
\hline 12 & 321622 & 4245108 & 8-Feb-01 & $14: 09$ & 0.931 & \\
\hline 13 & 321601 & 4245099 & 8-Feb-01 & $14: 12$ & 0.932 & \\
\hline 14 & 321559 & 4245096 & 8-Feb-01 & $14: 14$ & 0.931 & \\
\hline 15 & 321539 & 4245111 & 8-Feb-01 & $14: 15$ & 0.946 & \\
\hline 16 & 321563 & 4245135 & 8-Feb-01 & $14: 17$ & 0.963 & \\
\hline 17 & 321607 & 4245155 & 8-Feb-01 & $14: 19$ & 0.953 & \\
\hline 18 & 321580 & 4245097 & 8-Feb-01 & $14: 41$ & & Parking place for plane \\
\hline 19 & 321627 & 4245097 & 8-Feb-01 & $14: 42$ & 0.924 & \\
\hline 20 & 321715 & 4245117 & 8-Feb-01 & $14: 45$ & 0.948 & \\
\hline 21 & 321730 & 4245123 & 8-Feb-01 & $14: 47$ & 0.955 & \\
\hline 22 & 321699 & 4245174 & 8-Feb-01 & $14: 49$ & 0.953 & \\
\hline 23 & 321664 & 4245233 & 8-Feb-01 & $14: 52$ & 0.952 & white paint \\
\hline 24 & 321659 & 4245201 & 8-Feb-01 & $14: 54$ & 0.952 & \\
\hline 25 & 321713 & 4245115 & 8-Feb-01 & $14: 57$ & 0.955 & \\
\hline 26 & 321601 & 4245125 & 8-Feb-01 & 15:00 & 0.96 & battery died/replaced \\
\hline 27 & 321510 & 4245141 & 8-Feb-01 & 15:04 & 0.981 & drainage area, damp,sediment \\
\hline 28 & 321488 & 4245123 & 8-Feb-01 & 15:06 & 0.971 & \\
\hline 29 & 321540 & 4245131 & 8-Feb-01 & 15:09 & 0.954 & \\
\hline 30 & 321615 & 4245161 & 8-Feb-01 & $15: 13$ & 0.943 & Near Temp apparatus \\
\hline 31 & 321613 & 4245144 & 8-Feb-01 & 15:14 & 0.955 & \\
\hline 32 & 321600 & 4245134 & 8-Feb-01 & $15: 16$ & & \\
\hline & & & & & & \\
\hline \multicolumn{7}{|c|}{$\mathrm{E}=$ UTM East Datum=NAD 1983 in meters } \\
\hline $\mathbf{N}=$ & \multicolumn{3}{|c|}{ UTM North Datum=NAD 1983 in meters } & & & \\
\hline \multicolumn{6}{|c|}{$\mathrm{AE}=$ Effective emmisivity of tarmac from Heiman Radiometer } & \\
\hline
\end{tabular}




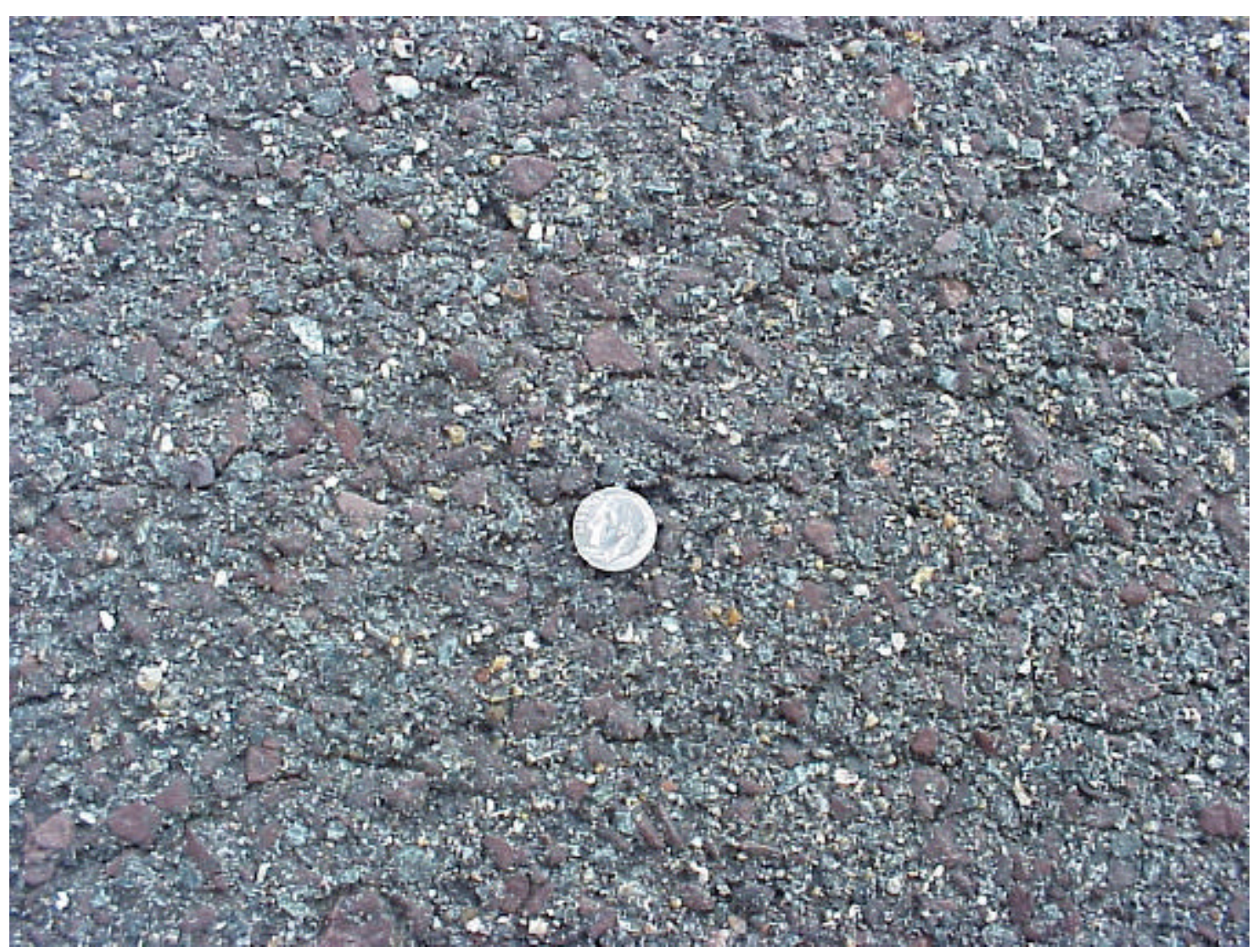

Figure 5. Close-up of the tarmac where the temperature apparatus was installed.

\section{DATA DESCRIPTION}

Table III contains a description of the structure of the data files, <enddate>.dat, which contains paved surface temperatures collected during this campaign. Time stamps are in Eastern Standard Time and are not adjusted for Daylight Savings Time.

Table III

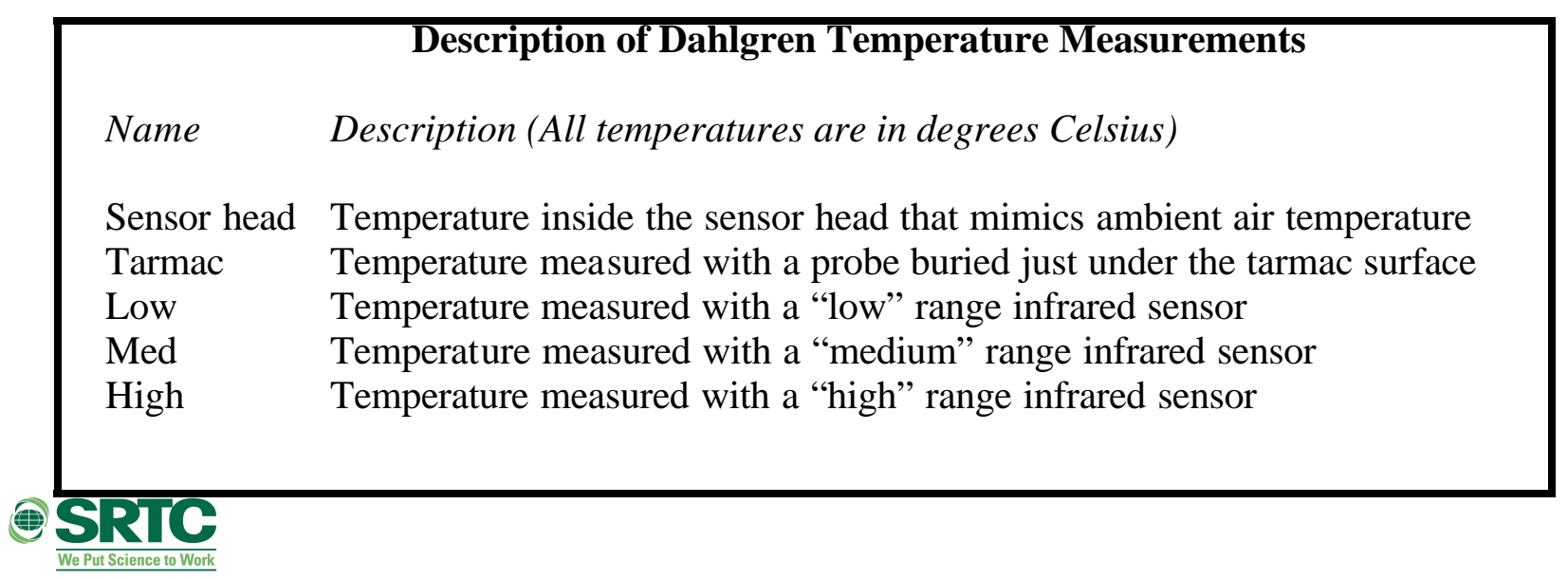


Note about the structure of the data file, which could be used for data parsing and analysis. The first column contains the number "127" except at 10:00 ("103") and 14:00 ("112") when different numbers are shown. At 10:00, the port settings of the datalogger ("2" means the setting is "high"), battery voltage (VDC), and panel temperature are shown. At 14:00, a blank location ("0"), port settings, and battery voltage are shown.

\section{QuAlity ASSurance}

Data were compiled and reviewed for accuracy for the entire period of collection. Table IV shows the quality assurance condition of each measurement value during each month of the collection campaign.

\section{Table IV}

\section{Data Quality Assurance Matrix}

$\mathrm{G}-(\mathrm{Good})$ - Data are good to use as-is. When using IR sensors, care should be taken to correctly match the range to condition.

Y - (Yellow) - Caution should be exercised when using data. Significant biases may be present and comparisons to the other IR sensors and Tarmac sensor should be made to determine suitability for use.

$\mathbb{R}$ - (Red) - $\quad$ Data are unusable. Another IR sensor or the Tarmac sensor must be used.

\begin{tabular}{|c|c|c|c|c|c|c|}
\hline YEAR & MONTH & SENSOR HEAD & ГARMAC & $\begin{array}{l}\text { LOW RANGE } \\
\mathbb{R}\end{array}$ & $\begin{array}{l}\text { MEDIUM } \\
\text { RANGE IR }\end{array}$ & $\begin{array}{l}\text { HIGH RANGE } \\
\mathbb{I R}\end{array}$ \\
\hline \multirow[t]{3}{*}{2001} & March & $G$ & $G$ & $G$ & $\mathrm{G}$ & $\mathrm{G}$ \\
\hline & April & $G$ & $G$ & $G$ & $G$ & $\begin{array}{l}\text { G-Mid month } \\
\text { Y-After mid } \\
\text { month }\end{array}$ \\
\hline & May & $G$ & $G$ & $G$ & G & I \\
\hline & Iune & $\mathrm{G}$ & $G$ & $\begin{array}{l}\text { G-Mid month } \\
\text {-After mid } \\
\text { month }\end{array}$ & $\begin{array}{l}\text { G-Mid month } \\
\text { Y-After mid } \\
\text { month }\end{array}$ & $\mathbf{R}$ \\
\hline & July & $G$ & $\mathrm{G}$ & $Y$ & Y & $\mathbf{R}$ \\
\hline & August & G & $G$ & $\begin{array}{l}\text { Y-Mid month } \\
\text { R-After mid } \\
\text { month }\end{array}$ & $\mathbf{R}$ & $\mathbf{R}$ \\
\hline & September & G & $G$ & $\begin{array}{l}\mathbf{R} \\
\mathbf{G} \text {-After } 9 / 27\end{array}$ & $\begin{array}{l}\mathbf{R} \\
\mathbf{G} \text {-After } 9 / 27\end{array}$ & $\begin{array}{l}\mathbf{R} \\
\mathbf{G} \text {-After 9/27 }\end{array}$ \\
\hline
\end{tabular}


WSRC-TR-2002-00487

Final MTI Data Report: Dahlgren Naval Surface Warfare Center (U)

Savannah River Technology Center

\begin{tabular}{|c|c|c|c|c|c|c|}
\hline & Pctober & G & G & $\begin{array}{l}\text { I-Day } \\
\text { G-Night }\end{array}$ & I & Y \\
\hline & November & G & G & $\begin{array}{l}\text { Y-Day } \\
\text { G-Night }\end{array}$ & $\begin{array}{l}\text { Y-Day } \\
\text { G-Night }\end{array}$ & Y \\
\hline & Pecember & G & G & $\mathrm{G}$ & $G$ & G \\
\hline 2002 & anuary & $\mathbf{G}$ & G & $\begin{array}{l}\text { G-Mid month } \\
\text { Y-Daytime after } \\
\text { mid month }\end{array}$ & $\begin{array}{l}\text { G-Mid month } \\
\text { Y-After mid } \\
\text { month }\end{array}$ & $\begin{array}{l}\text { G-Mid month } \\
\text { Y-After mid } \\
\text { month }\end{array}$ \\
\hline & February & G & G & $G$ & $Y$ & Y \\
\hline & March & G & G & G & $\begin{array}{l}\text { G-Except during } \\
\text { warm days }\end{array}$ & Y \\
\hline & April & G & $G$ & $G$ & $G$ & Y \\
\hline & May & $G$ & $G$ & $\begin{array}{l}\text { G-Mid month } \\
\text {-After mid } \\
\text { month }\end{array}$ & $\begin{array}{l}\text { Y-Mid month } \\
\mathbf{R} \text {-After mid } \\
\text { month }\end{array}$ & $\mathbf{R}$ \\
\hline & Tune & G & G & $\begin{array}{l}\text { Y-Mid month } \\
\mathbf{R} \text {-After mid } \\
\text { month }\end{array}$ & $\mathbf{R}$ & $\mathbf{R}$ \\
\hline & unly & G & $G$ & $\mathbf{R}$ & $\mathbf{R}$ & $\mathbf{R}$ \\
\hline
\end{tabular}

\section{Example Data Plots}

The following plots show examples of paved surface temperature data collected in 2001 . The captions provide information on the relative accuracies of the data shown. 
Final MTI Data Report: Dahlgren Naval Surface Warfare Center (U)

Savannah River Technology Center

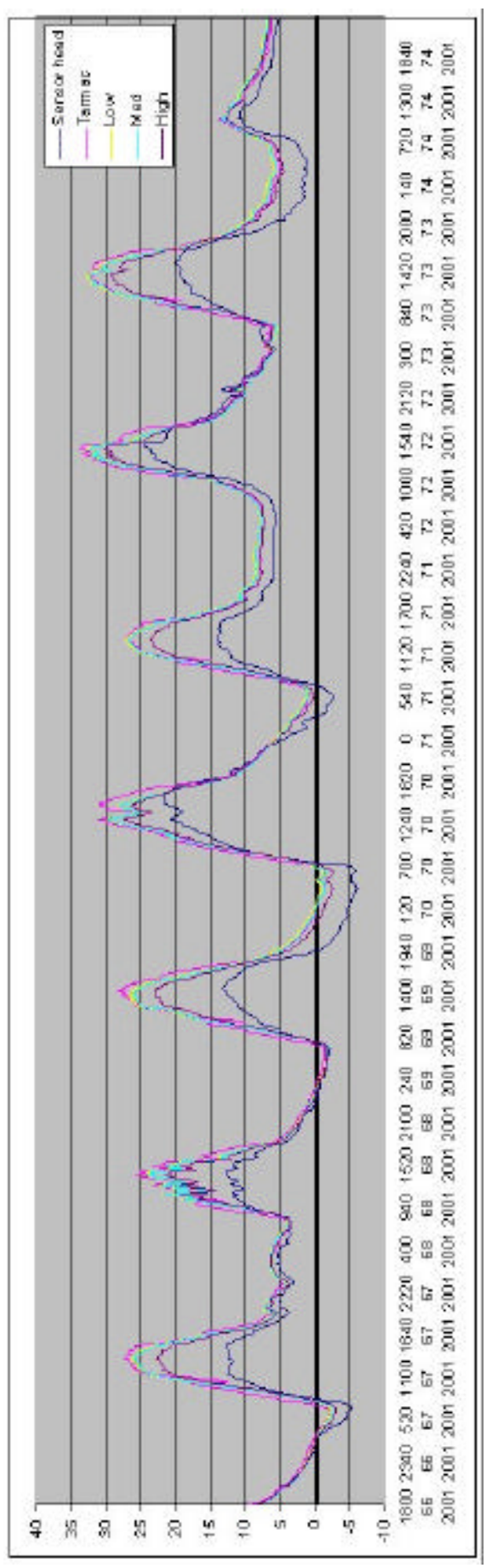

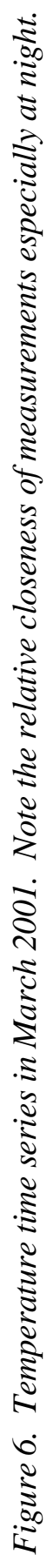

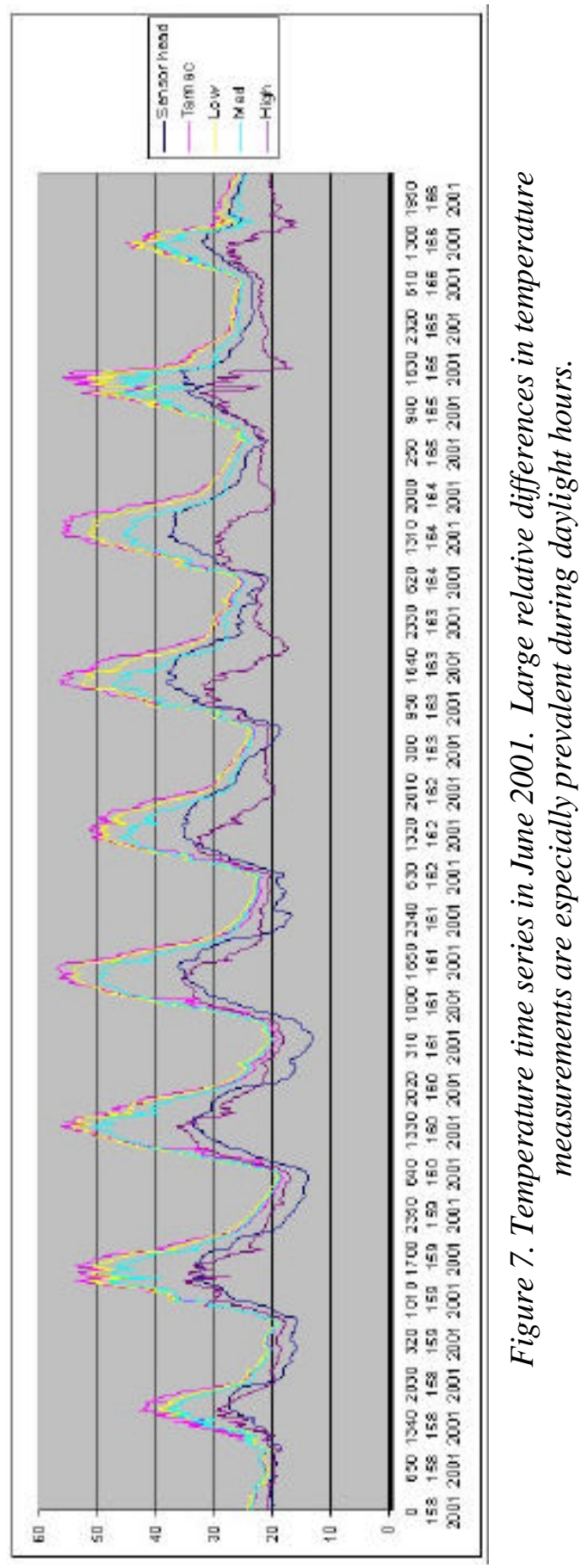

October 2002 
WSRC-TR-2002-00487

Final MTI Data Report: Dahlgren Naval Surface Warfare Center (U)

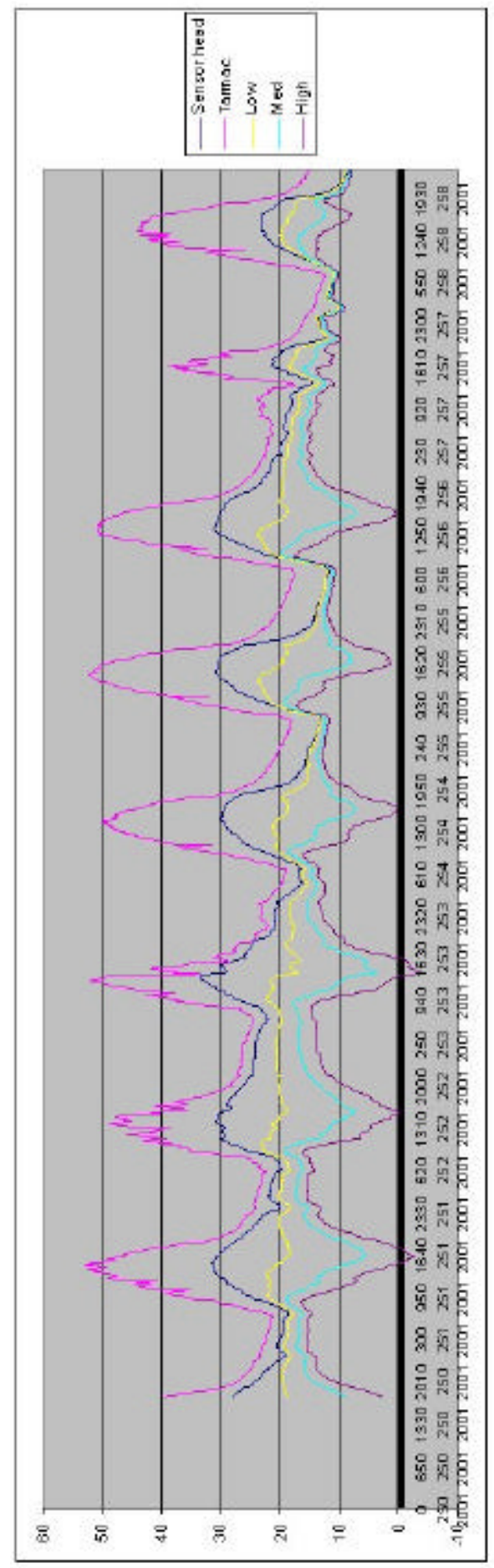

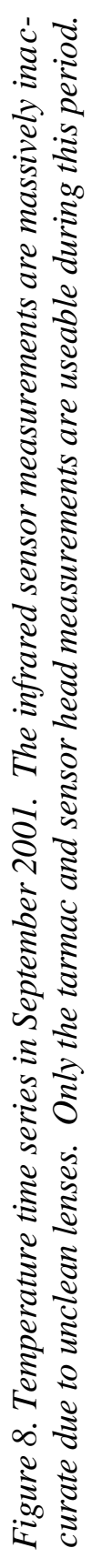

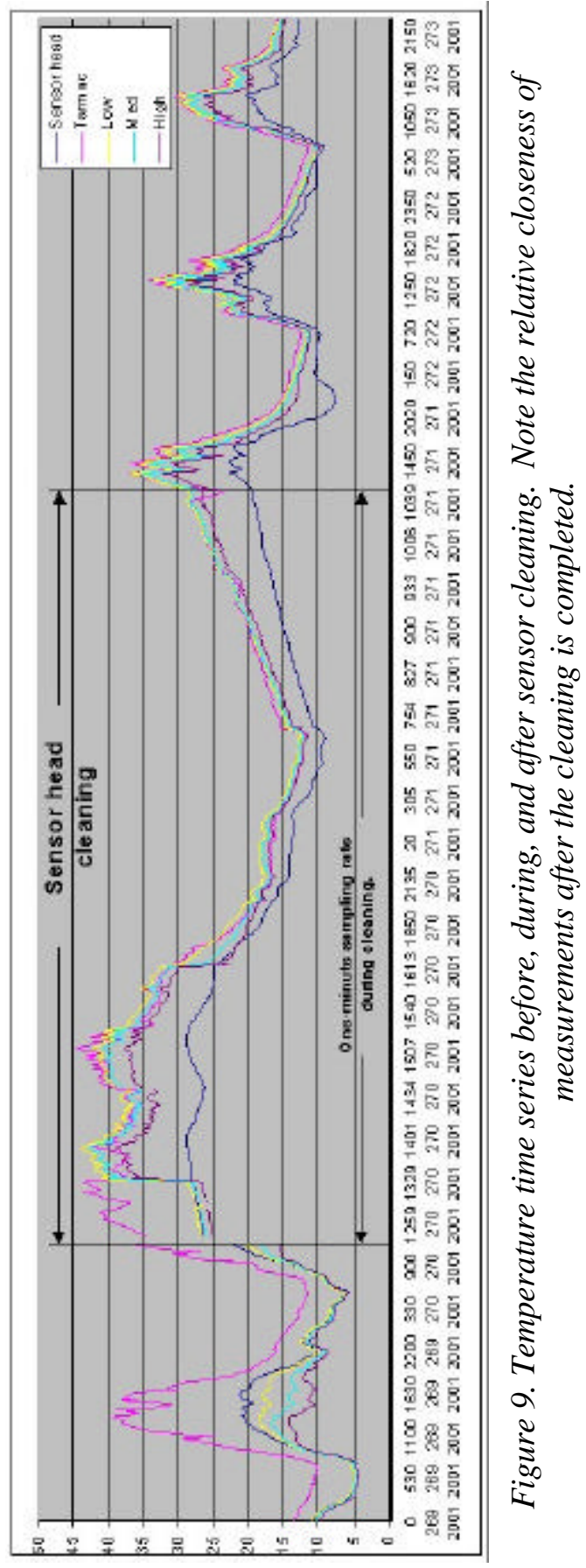


Final MTI Data Report: Dahlgren Naval Surface Warfare Center (U)

Savannah River Technology Center
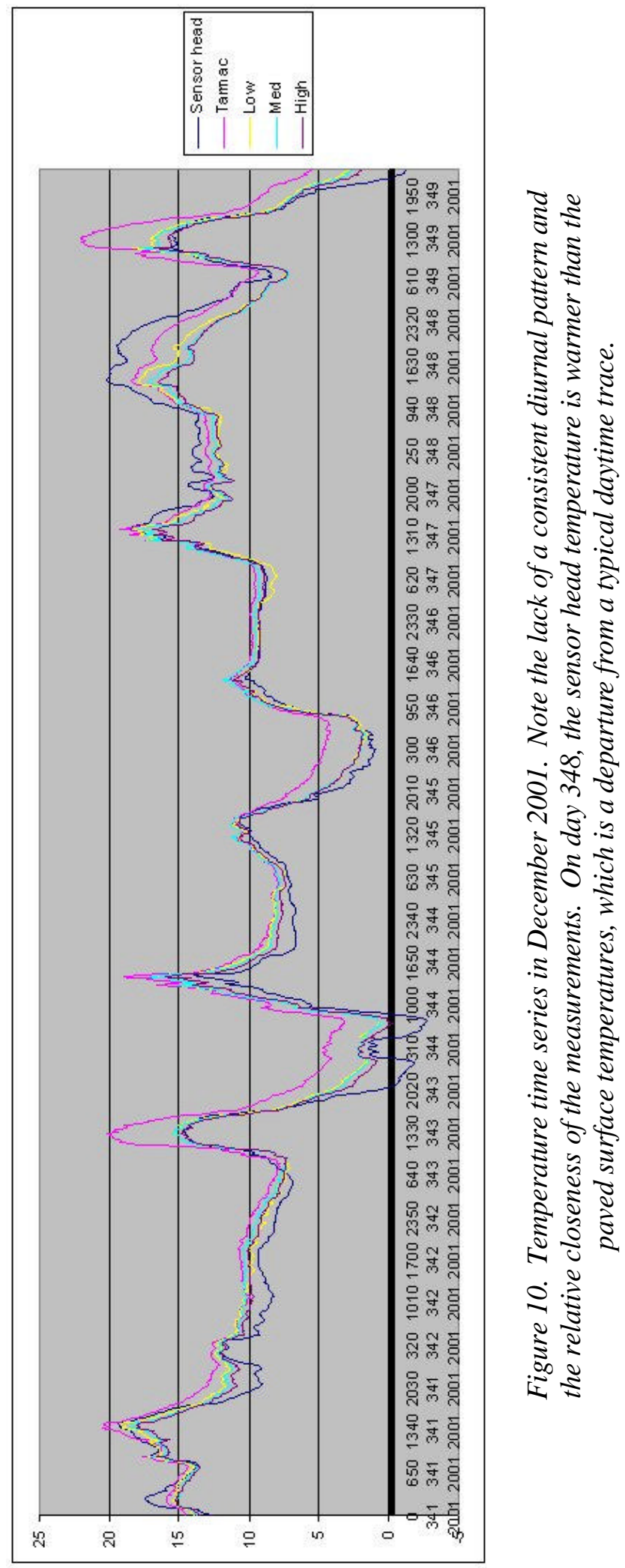

October 2002 


\section{ACKNOWLEDGEMENTS}

A special thanks goes to Ron Copeland at the Dahlgren Naval Surface Warfare Center for supporting the deployment and operation of the paved surface temperature apparatus.

\section{REFERENCES}

Garrett, A. J., R. J. Kurzeja, B. L. O’Steen, M. J. Parker, M. M. Pendergast, and E. VillaAleman, 1999: Ground-Truth Measurements Plan for the Multispectal Thermal Imager (MTI) Satellite. WSRC-TR-99-00455. Westinghouse Savannah River Company, Aiken, SC. 